Jurnal Pendidikan Akuntansi Indonesia, Vol. IX. No. 1 - Tahun 2011, Hlm. 1 - 23

\title{
DETERMINAN KUALITAS IMPLEMENTASI CORPORATE GOVERNANCE PADA PERUSAHAAN YANG TERDAFTAR DI BURSA EFEK INDONESIA (BEI) PERIODE 2004-2008
}

\author{
Oleh \\ Abdullah Taman ${ }^{1}$ \\ Bily Agung Nugroho ${ }^{2}$
}

\begin{abstract}
Objective of this paper is to analyze determinant of implementation quality of corporate governance in companies listing in Indonesian Stock Exchange during period 20042008.

Population in this study is entire listed companies in Indonesia Capital Market amount to 389 companies. Purposive samping is used to determine sample usage. The samples are fifty companies but one company is relaxed because of outlier. Analysis method used in this study is multiple regression.

This study concludes that determinants of implementation quality of corporate governance are ownership concentration, investment opportunity set, and leverage. Simultaneously, they affect significantly to implementation quality of corporate governance with F-value is 3.301 (sig. 0.029). Meanwhile, individually variable leverage affects significantly to implementation quality of corporate governance with t-value is 2.694 (sig. $0.016)$.
\end{abstract}

Key words: corporate governance, ownership concentration, investment opportunity set, leverage.

\section{PENDAHULUAN}

Pemisahan fungsi kepemilikan dan fungsi pengendalian dalam hubungan keagenan sering menimbulkan masalah-masalah keagenan. Masalah-masalah keagenan tersebut timbul karena adanya konflik dan perbedaan kepentingan antara principal (pemilik perusahaan atau pihak yang memberikan mandat) dan agent (manajer perusahaan atau pihak yang menerima mandat). Namun, kontrak yang efisien belum cukup untuk mengatasi masalah keagenan. Konsep corporate governance timbul karena adanya keterbatasan dari teori keagenan dalam mengatasi masalah keagenan dan dapat dipandang dari kelanjutan teori keagenan (Ariyoto dalam Deni Darmawati, 2006: 2). Corporate governance merupakan cara untuk memberikan keyakinan kepada para pemasok dana perusahaan akan diperolehnya pengembalian (return) atas investasi mereka, selain itu corporate governance juga merupakan suatu sistem untuk mengarahkan (direct) dan mengendalikan (control) suatu perusahaan atau korporasi.

Corporate governance mulai menjadi isu yang hangat dibicarakan sejak terjadinya skandal bisnis yang mengindikasikan lemahnya corporate governance di perusahaanperusahaan Inggris pada sekitar tahun 1950-an dan semakin berlanjut hingga menimbulkan resesi ditahun 1980-an (Davies dalam Deni Darmawati, 2006: 2). Di Indonesia, isu mengenai corporate governance mulai mengemuka setelah Indonesia mengalami masa krisis yang

\footnotetext{
${ }^{1}$ Dosen Jurusan Pendidikan Akuntansi - Universitas Negeri Yogyakarta

${ }^{2}$ Praktisi pada PT Adhi Karya (Persero) Tbk
} 
berkepanjangan sejak tahun 1998. Banyak pihak mengatakan bahwa lamanya proses perbaikan krisis ekonomi di Indonesia dikarenakan oleh lemahnya corporate governance yang diterapkan pada perusahaan di Indonesia. Sejak saat itu, baik pemerintah maupun investor mulai memberikan perhatian yang cukup signifikan dalam praktik corporate governance di Indonesia.

Akhir-akhir ini, sebagian besar negara (termasuk Indonesia) telah memiliki badan/lembaga/institusi yang bertugas membentuk prinsip-prinsip corporate governance yang disesuaikan dengan kondisi lingkungan bisnis di negara yang bersangkutan. Bank dunia dan Organization for Economic Co-operation and Development (OECD) telah memberikan konstribusi penting dalam pengembangan prinsip-prinsip corporate governance di berbagai negara. Di berbagai negara bahkan sudah dilakukan pemeringkatan implementasi corporate governance di tingkat perusahaan. Di Indonesia, pemeringkatan penerapan corporate governance bagi perusahaan yang terdaftar di Bursa Efek Indonesia (BEI) sudah dilakukan oleh The Indonesian Institute for Corporate Governance (IICG) setiap tahun sejak tahun 2001 dengan nama Corporate Governance Perception Index (CGPI).

Perusahaan-perusahaan yang masuk dalam peringkat sepuluh besar Corporate Governance Perception Index (CGPI) merupakan perusahaan yang memiliki kualitas corporate governance terbaik di Indonesia. Keberadaan perusahaan-perusahaan tersebut tentunya menjadi daya tarik tersendiri bagi para investor dan kreditor. Hal tersebut dikarenakan kualitas implementasi corporate governance yang baik (selanjutnya disebut Good Corporate Governance) telah terbukti mampu meningkatkan kemajuan bagi perusahaan melalui kinerja yang selalu meningkat dan tingkat kesehatan perusahaan yang semakin membaik sehingga mampu menghilangkan kecurigaan dari pihak lain. Selain itu, Good Corporate Governance (GCG) mampu menjamin perusahaan dalam keadaan sustainabled (terpelihara) dari iklim bisnis yang tidak sehat (Swa Sembada, 2009: 89-104).

Faktor-faktor yang mempengaruhi penerapan corporate governance dapat bervariasi dikarenakan adanya variasi manfaat pengendalian yang diberikan dan biaya yang ditimbulkan dari manajer serta konsentrasi kepemilikan (pemegang saham pengendali) perusahaan (Gillan et.al., 2003: 27). Oleh karena masalah keagenan bervariasi antar perusahaan, maka biaya dan manfaat bersih dari berbagai alternatif struktur corporate governance yang digunakan untuk mengendalikan masalah-masalah keagenan tersebut juga bervariasi. Konsentrasi kepemilikan (pemegang saham kendali) di suatu perusahaan dapat mempengaruhi implementasi strategi organisasi jika perusahaan tesebut mayoritas modalnya berasal dari saham atau surat berharga lainnya, sehingga para pemegang saham pengendali perusahaan dapat mempengaruhi kualitas implementasi corporate governance pada perusahaan tersebut melalui penerapan kebijakan yang mereka rancang.

Sebuah perusahaan yang dipimpin oleh seorang Chief Executive Officer (CEO) yang memiliki saham dalam perusahaan tersebut (konsentrasi kepemilikan) kemungkinan dapat mempengaruhi kinerja dan implementasi corporate governance perusahaan tersebut. Sehingga banyak pertanyaan yang muncul, bagaimana pelaksanaan kinerja perusahaan dan implementasi corporate governance dipengaruhi oleh hal tersebut. Namun, di sisi lain kelemahan sistem hukum atau proteksi terhadap investor menjadi salah satu masalah dalam implementasi corporate governance, maka dari itu konsentrasi kepemilikan dapat menjadi alat yang lebih penting untuk mengatasi masalah keagenan (Durnev dan Kim, 2003: 28), meskipun terkadang konsentrasi kepemilikan dapat menurunkan kualitas corporate governance suatu perusahaan atau bahkan tidak berpengaruh sama sekali.

Dalam kaitannya dengan set kesempatan investasi (investment opportunities set), bagi perusahaan yang memiliki set kesempatan investasi tinggi senantiasa melakukan ekspansi dalam strategi bisnisnya, maka akan semakin membutuhkan dana eksternal. Durnev dan Kim menjelaskan bahwa dengan adanya set kesempatan investasi yang menguntungkan, maka 
return dari para pemegang saham pengendali akan lebih besar dibanding manfaat yang akan mereka peroleh jika melakukan diskresi (kebebasan bertindak dalam mengambil keputusan) terhadap sumber daya perusahaan (Durnev dan Kim, 2003: 27). Adanya hal tersebut memungkinkan perusahaan untuk dapat meningkatkan kualitas implementasi corporate governance berdasarkan set kesempatan investasi yang ada.

Penggunaan struktur modal (leverage) pada suatu perusahaan ternyata juga dapat mempengaruhi implementasi kualitas corporate governance suatu perusahaan. Black et.al., menyimpulkan bahwa perusahaan yang memiliki tingkat utang yang tinggi dalam struktur modalnya akan cenderung diawasi oleh kreditor karena akibat dari adanya kontrak utang yang dibuat. Dengan adanya hal yang demikian, maka perusahaan cenderung kurang begitu memperhatikan kualitas corporate governance-nya karena adanya pengawasan dari pihak eksternal (kreditor). Begitu pula sebaliknya, apabila komposisi struktur modal saham (pendanaan internal) perusahaan lebih besar, maka investor (pemegang saham) memiliki kekuasaan yang lebih besar untuk memaksa perusahaan meningkatkan kualitas implementasi corporate governance-nya. Namun, terkadang komposisi utang dalam struktur modal perusahaan memiliki tingkat pengaruh yang rendah terhadap kualitas implementasi corporate governance pada perusahaan-perusahaan tertentu (Black et. al., 2006: 14-15).

Tujuan artikel ini adalah untuk menganalisis detrminan kualitas implementasi corporate governance pada perusahaan yang masuk dalam sepuluh besar di Corporate Governance Perception Index (CGPI). Sistematika setelah pendahuluan ini dilanjutkan dengan pengembangan teori dan hipotesis, metode penelitian, hasil penelitian, pembahasan, serta diakhiri dengan kesimpulan.

\section{PENGEMBANGAN TEORI DAN HIPOTESIS}

\section{Teori Keagenan (Agency Theory)}

Perspektif hubungan keagenan merupakan dasar yang digunakan untuk memahami corporate governance. Jensen dan Meckling menyatakan bahwa hubungan keagenan adalah sebuah kontrak antara manajer (agent) dengan investor (principal) (Jensen dan Meckling, 1976: 5). Konflik kepentingan antara pemilik dan agen terjadi karena kemungkinan agen tidak selalu berbuat sesuai dengan kepentingan principal, sehingga memicu biaya keagenan (agency cost). Eisenhardt menyatakan bahwa teori agensi menggunakan tiga asumsi sifat manusia yaitu: (1) manusia pada umumya mementingkan diri sendiri (self interest), (2) manusia memiliki daya pikir terbatas mengenai persepsi masa mendatang (bounded rationality), dan (3) manusia selalu menghindari risiko (risk averse) (Eisenhardt, 1989: 2).

Manajer sebagai pengelola perusahaan lebih banyak mengetahui informasi internal dan prospek perusahaan di masa yang akan datang dibandingkan pemilik (pemegang saham). Manajer berkewajiban memberikan sinyal mengenai kondisi perusahaan kepada pemilik. Sinyal yang diberikan dapat dilakukan melalui pengungkapan informasi akuntansi seperti laporan keuangan. Laporan keuangan tersebut penting bagi para pengguna informasi eksternal terutama karena kelompok ini berada dalam kondisi yang paling besar ketidakpastiannya. Ketidakseimbangan penguasaan informasi akan memicu munculnya suatu kondisi yang disebut sebagai informasi asimetris (information asymmetry). Asimetri antara manajemen (agent) dengan pemilik (principal) dapat memberikan kesempatan kepada manajer untuk melakukan manajemen laba (earnings management) dalam rangka menyesatkan pemegang saham mengenai kinerja ekonomi perusahaan (Haris dalam Rudi Isnanta, 2008: 1).

Corporate governance yang merupakan konsep yang didasarkan pada teori keagenan, diharapkan bisa berfungsi sebagai alat untuk memberikan keyakinan kepada para investor bahwa mereka akan menerima return atas dana yang telah mereka investasikan. Corporate governance berkaitan erat dengan bagaimana para investor yakin bahwa manajer akan 
memberikan keuntungan bagi mereka dan yakin bahwa manajer tidak akan mencuri atau menggelapkan atau menginvestasikan ke dalam projek-projek yang tidak menguntungkan berkaitan dengan dana kapital yang telah ditanamkan oleh investor, dan berkaitan dengan bagaimana para investor mengontrol para manajer (Muh. Arif dan Bambang, 2007: 6). Dengan kata lain corporate governance diharapkan dapat berfungsi untuk menekan atau menurunkan biaya keagenan (agency cost).

\section{Corporate Governance}

Pengertian corporate governance dapat dimasukkan dalam dua kategori (Indra Surya dan Ivan Yustiavandana dalam Yunita Heryani Mintara, 2008: 12). Kategori pertama, lebih condong pada serangkaian pola perilaku perusahaan yang diukur melalui kinerja, pertumbuhan, struktur pembiayaan, perlakuan terhadap para pemegang saham, dan stakeholders. Kategori kedua lebih cenderung pada kerangka secara normatif, yaitu segala ketentuan hukum baik yang berasal dari sistem hukum, sistem peradilan, pasar keuangan, dan sebagainya yang mempengaruhi perilaku perusahaan. Corporate governance merupakan kumpulan hukum, peraturan dan kaidah yang wajib dipenuhi, yang dapat mendorong kinerja perusahaan agar bekerja secara efisien, dan mampu menghasilkan nilai ekonomi jangka panjang yang berkesinambungan bagi para pemegang saham maupun masyarakat sekitar secara keseluruhan.

Menurut Komite Nasional Kebijakan Governance (KNKG), Good Corporate Governance (GCG) adalah salah satu pilar dari sistem ekonomi pasar. Corporate governance berkaitan erat dengan kepercayaan baik terhadap perusahaan yang melaksanakannya maupun terhadap iklim usaha di suatu negara. Penerapan Good Corporate Governance (GCG) mendorong terciptanya persaingan yang sehat dan iklim usaha yang kondusif (KNKG dalam Diah Kusuma Wardani, 2008: 7). Oleh karena itu, diterapkannya Good Corporate Governance (GCG) bagi perusahaan-perusahaan di Indonesia sangat penting untuk menunjang pertumbuhan dan stabilitas ekonomi yang berkesinambungan.

Corporate governance pada dasarnya merupakan hubungan partisipan dalam menentukan arah dan kinerja. Menurut The Indonesian Institute of Corporate Governance (IICG), Good Corporate Governance (GCG) didefinisikan sebagai struktur, sistem, dan proses yang digunakan oleh organ-organ perusahaan sebagai upaya untuk memberi nilai tambah perusahaan secara berkesinambungan dalam jangka panjang dengan tetap memperhatikan kepentingan stakeholders lainnya berdasarkan peraturan perundangan dan norma yang berlaku (IICG, 2009: 3). Corporate governance juga mensyaratkan adanya struktur perangkat untuk mencapai tujuan dan pengawasan atas kinerja.

\section{Prinsip-prinsip Corporate Governance}

Prinsip-prinsip utama dari Good Corporate Governance (GCG) yang menjadi indikator, sebagaimana yang telah dirancang oleh The Indonesian Intitute of Corporate Governance (IICG, 2009: 12-13) dan Organization for Economic Cooperation and Development (OECD, 2004: 49-58) yaitu:

a. Fairness (Keadilan)

Keadilan merupakan prinsip perlakuan yang adil bagi seluruh pemegang saham. Keadilan yang diartikan sebagai perlakuan yang sama terhadap para pemegang saham, terutama kepada pemegang saham minoritas dan pemegang saham asing dari kecurangan, dan kesalahan perilaku insider. Dalam melaksanakan kegiatannya, perusahaan harus senantiasa memperhatikan kepentingan pemegang saham dan pemangku kepentingan lainnya berdasarkan asas kewajaran dan kesetaraan.

b. Disclosure/Transparency (Keterbukaan/Tranparansi) 
Transparansi adalah pengungkapan yang akurat dan tepat pada waktunya serta transparansi atas hal penting bagi kinerja perusahaan, kepemilikan, serta pemegang kepentingan. Untuk menjaga obyektivitas dalam menjalankan bisnis, perusahaan harus menyediakan informasi yang material dan relevan dengan cara yang mudah diakses dan dipahami oleh pemangku kepentingan. Perusahaan harus mengambil inisiatif untuk mengungkapkan tidak hanya masalah yang disyaratkan oleh peraturan perundang-undangan, tetapi juga hal yang penting untuk pengambilan keputusan oleh pemegang saham, kreditor, dan pemangku kepentingan lainnya.

c. Accountabillity (Akuntabilitas)

Akuntabilitas menekankan pada pentingnya penciptaan sistem pengawasan yang efektif berdasarkan pembagian kekuasaan antara komisaris, direksi, dan pemegang saham yang meliputi monitoring, evaluasi serta pengendalian terhadap manajemen untuk meyakinkan bahwa manajemen bertindak sesuai dengan kepentingan pemegang saham dan pihak-pihak berkepentingan lainnya. Akuntabilitas merupakan prasyarat yang diperlukan untuk mencapai kinerja yang berkesinambungan.

d. Responsibility (Responsibilitas)

Responsibilitas adalah tanggung jawab pengurus dalam manajemen, pengawasan manajemen serta pertanggungjawaban kepada perusahaan dan para pemegang saham. Prinsip ini diwujudkan dengan kesadaran bahwa tanggungjawab merupakan konsekuensi logis dari adanya wewenang, menyadari akan adanya tanggungjawab sosial, menghindari penyalahgunaan wewenang kekuasaan, menjadi professional, dan menjunjung etika serta memelihara bisnis yang sehat.

e. Independency (Independen)

Adanya masing-masing organ perusahaan yang tidak saling mendominasi dan tidak dapat diintervensi oleh pihak lain merupakan salah satu bentuk independensi dalam suatu perusahaan. Independen diperlukan untuk menghindari adanya potensi konflik kepentingan yang mungkin timbul oleh para pemegang saham mayoritas. Mekanisme ini menuntut adanya rentang kekuasaan antara komposisi komisaris, komite dalam komisaris, dan pihak luar seperti auditor. Keputusan yang dibuat dan proses yang terjadi harus objektif dan tidak dipengaruhi oleh kekuatan pihak-pihak tertentu.

Dengan adanya pedoman Good Corporate Governance (GCG) yang telah dibuat oleh Komite Nasional Kebijakan Governance (KNKG) hendaknya dijadikan kode etik perusahaan yang dapat memberikan acuan pada pelaku usaha untuk melaksanakan Good Corporate Governance (GCG) secara konsisten dan konsekuen. Hal ini penting, mengingat kecenderungan aktivitas usaha yang semakin mengglobal, maka prinsip-prinsip corporate governance (keadilan, transparasi, akuntabilitas, responsibilitas, dan independen) dapat dijadikan sebagai ukuran perusahaan untuk menghasilkan suatu kinerja perusahaan yang lebih baik.

Penerapan prinsip-prinsip Good Corporate Governance (GCG) dalam suatu perusahaan merupakan salah satu bahan pertimbangan utama bagi kreditor dalam mengevaluasi potensi suatu perusahaan untuk menerima pinjaman kredit. Bagi perusahaan yang berdomisili di negara-negara berkembang, implementasi aspek corporate governance secara konkret dapat memberikan kontribusi untuk memulihkan kepercayaan para kreditor terhadap kinerja suatu perusahaan yang telah dilanda krisis, misalnya di Indonesia. Di dunia Internasional, penerapan Good Corporate Governance (GCG) sudah merupakan suatu syarat utama dalam perjanjian pemberian kredit. Seringkali perusahaan yang telah mengimplementasikan prinsip-prinsip Good Corporate Governance (GCG) mempunyai kemungkinan besar untuk memperoleh bantuan kredit bagi usahanya.

Penerapan prinsip-prinsip Good Corporate Governance (GCG) ditujukan untuk menghasilkan kinerja perusahaan yang efektif dan efisien melalui harmonisasi manajemen 
perusahaan. Dalam penerapan prinsip-prinsip GCG tersebut dibutuhkan peran yang penuh komitmen dan independen dari dewan direksi dan dewan komisaris dalam menjalankan kegiatan perusahaan untuk menghasilkan kinerja perusahaan yang baik. Prinsip-prinsip dasar dari Good Corporate Governance (GCG) pada dasarnya memiliki tujuan untuk memberikan kemajuan terhadap kinerja suatu perusahaan. Secara konkret, penerapan prinsip-prinsip Good Corporate Governance (GCG) memiliki tujuan sebagai berikut (Yuthi Aghnia, 2009: 1):

a) Mendorong tercapainya kesinambungan perusahaan melalui pengelolaan yang didasarkan pada asas transparansi, akuntabilitas, responsibilitas, independensi serta kesetaraan dan kewajaran.

b) Mendorong pemberdayaan fungsi dan kemandirian masing-masing organ perusahaan, yaitu Dewan Komisaris, Direksi, dan Rapat Umum Pemegang Saham.

c) Mendorong pemegang saham, anggota Dewan Komisaris, dan anggota Direksi agar dalam membuat dan menjalankan tindakannya dilandasi oleh nilai moral yang tinggi dan kepatuhan terhadap peraturan perundang-undangan.

d) Mendorong timbulnya kesadaran dan tanggung jawab sosial perusahaan terhadap masyarakat dan kelestarian lingkungan terutama di sekitar perusahaan.

e) Mengoptimalkan nilai perusahaan bagi pemegang saham dengan tetap memperhatikan pemangku kepentingan lainnya.

f) Meningkatkan daya saing perusahaan secara nasional maupun internasional, sehingga mampu menigkatkan kepercayaan pasar yang dapat mendorong arus investasi dan pertumbuhan ekonomi nasional yang berkesinambungan.

\section{Kualitas Implementasi Corporate Governance}

Kualitas implementasi corporate governance merupakan sebuah penilaian tentang tata kelola perusahaan yang selanjutnya memunculkan predikat (terdiri atas predikat "sangat terpercaya", "terpercaya", dan "cukup terpercaya") bagaimana Good Corporate Governance (GCG) diimplementasikan oleh suatu perusahaan. Penilaian Corporate Governance Perception Index (CGPI) meliputi empat bobot nilai yang berbeda, diantaranya adalah self assessment (15\%), kelengkapan dokumen (25\%), makalah (12\%), dan observasi (48\%). Nilai CGPI dihitung dengan menjumlahkan nilai akhir dari pemenuhan regulasi, kebijakan, pedoman, dan praktik terbaik dalam penerapan Good Corporate Governance (GCG) di Indonesia dan negara lain. Secara keseluruhan dipersyaratkan sekurang-kurangnya 40 dokumen untuk Perusahaan Publik dan 36 dokumen untuk BUMN (IICG, 2006: 7 dan 37). Sedangkan dalam tahap makalah dinilai berdasarkan perancangan makalah yang me refleksikan program dan hasil penerapan Good Corporate Governance (GCG) sebagai sebuah kesatuan sistem di perusahaan peserta CGPI, tema dan kaidah-kaidah dalam pembuatan makalah ditentukan oleh IICG. Penyusunan makalah dimaksudkan untuk membantu pihak perusahaan memaparkan upayanya dalam menerapkan Good Corporate Governance (GCG) pada saat observasi (IICG, 2006: 7 dan 38).

Tahap penilaian observasi merupakan kegiatan peninjauan langsung ke seluruh perusahaan peserta CGPI untuk memastikan praktik penerapan Good Corporate Governance (GCG) sebagai sebuah sistem pengelolaan bisnis di perusahaan tersebut. Pelaksanaan observasi di setiap perusahaan peserta CGPI dilakukan maksimal selama 1 (satu) hari kerja, yang dibagi ke dalam dua sesi forum diskusi, yaitu satu sesi forum diskusi dengan dewan komisaris dan direksi, dan satu sesi forum diskusi lainnya dengan manajemen fungsional. Tahapan observasi memiliki bobot yang paling besar dengan mempertimbangkan proses peninjauan langsung untuk memastikan data, informasi, dan proses bisnis perusahaan yang mendorong penegakkan prinsip Good Corporate Governance (GCG) (IICG, 2006: 7 dan 38). 
Rating level penilaiannya adalah sebagai berikut:

Tabel 1: Tabel Rating Penilaian CGPI

\begin{tabular}{|c|c|}
\hline $\begin{array}{c}\text { Kriteria Kualitas Implementasi } \\
\text { Corporate Governance }\end{array}$ & $\begin{array}{c}\text { Rating Level } \\
\text { Nilai CGPI }\end{array}$ \\
\hline Sangat Terpercaya & $85,00-100$ \\
\hline Terpercaya & $70,00-84,99$ \\
\hline Cukup Terpercaya & $55,00-69,99$ \\
\hline
\end{tabular}

(Sumber: The Indonesian Institute of Corporate Governance dan SWA Sembada No. 27/XXIV/18 Desember 2008)

\section{Konsentrasi Kepemilikan}

Penerbitan saham merupakan salah satu pilihan perusahaan ketika memutuskan untuk pendanaan perusahaan. Pada sisi yang lain, saham merupakan instrumen investasi yang banyak dipilih para investor karena saham mampu memberikan tingkat keuntungan yang menarik. Saham dapat didefinisikan sebagai tanda penyertaan modal seseorang atau pihak (badan usaha) dalam suatu perusahaan atau perseroan terbatas (Jogiyanto, 2008: 112). Dengan menyertakan modal tersebut, maka pihak tersebut memiliki klaim atas pendapatan perusahaan, klaim atas asset perusahaan, dan berhak hadir dalam Rapat Umum Pemegang Saham (RUPS). Obligasi merupakan surat utang jangka menengah-panjang yang dapat dipindahtangankan yang berisi janji dari pihak yang menerbitkan untuk membayar imbalan berupa bunga pada periode tertentu dan melunasi pokok utang pada waktu yang telah ditentukan kepada pihak pembeli obligasi tersebut (Jogiyanto, 2008: 146).

Apabila terdapat perusahaan yang menggunakan saham ataupun obligasi dalam mendanai aktivitas bisnisnya, kemungkinan besar perusahaan tersebut memiliki sekelompok pemegang kendali atas aktivitas bisnis perusahaan. Pada umumnya kelompok pengendali aktivitas bisnis perusahaan tersebut juga memiliki hak atas kepemilikan perusahaan atas dana yang mereka investasikan, sehingga kepemilikan perusahaan secara otomatis juga akan terkonsentrasi kepada kelompok yang dimaksud.

Konsentrasi kepemilikan menggambarkan bagaimana dan siapa saja yang memegang kendali atas keseluruhan atau sebagian besar atas kepemilikan perusahaan serta keseluruhan atau sebagian besar pemegang kendali atas aktivitas bisnis pada suatu perusahaan. Kepemilikan dikatakan lebih terkonsentrasi jika untuk mencapai kontrol dominasi atau mayoritas dibutuhkan penggabungan lebih sedikit investor. Adanya kontrol dalam suatu perusahaan yang dapat dipegang oleh semakin sedikit investor maka akan semakin mudah kontrol tersebut dijalankan. Dibandingkan dengan mekanisme pemegang saham besar, kepemilikan terkonsentrasi memiliki kekuatan kontrol yang lebih rendah karena mereka tetap harus melakukan koordinasi untuk menjalankan hak kontrolnya. Namun pada sisi yang lain mekanisme kepemilikan terkonsentrasi juga memiliki kemungkinan yang lebih kecil untuk munculnya peluang bagi kelompok investor yang terkonsentrasi untuk mengambil tindakan yang merugikan investor yang lain.

\section{Pengaruh Konsentrasi Kepemilikan terhadap Kualitas Implementasi Corporate Governance Perusahaan}

Kepemilikan saham yang besar oleh pihak tertentu dalam suatu perusahaan akan memiliki beberapa dampak terhadap kualitas implementasi corporate governance perusahaan 
tersebut. Drobetz et. al. menyatakan bahwa terdapat dua dampak utama dari besarnya saham yang dimiliki oleh pihak tertentu (Drobetz et. al., 2004: 6). Pertama, dengan meningkatnya hak atas aliran kas dari pemegang saham terbesar dalam suatu perusahaan, maka akan menimbulkan dampak positif yaitu kualitas implementasi corporate governance yang semakin membaik, yang kemudian pasar akan mengapresiasi, sehingga nilai perusahaan akan meningkat dan selanjutnya berdampak positif pada nilai saham yang mereka miliki (pemegang saham terbesar). Dengan demikian, para pemegang saham tersebut akan mendapatkan insentif dalam meningkatkan kualitas implementasi corporate governance perusahaan yang bersangkutan. Pandangan kedua, dengan semakin terkonsentrasinya kepemilikan perusahaan, maka pemegang saham mayoritas akan semakin menguasai perusahaan dan semakin mempengaruhi pengambilan keputusan (dampak negatif). Sehingga, para pemegang saham mayoritas tersebut berpendapat bahwa bukan menjadi kepentingan mereka lagi mengenai perlindungan kepada pemegang saham minoritas, perlunya transparasi, dan beberapa mekanisme corporate governance lainnya yang merupakan komponen dari pemeringkatan corporate governance. Jika hal tersebut terjadi, maka tata kelola perusahaan hanya akan mengarah pada salah satu pemegang kepentingan saja (pemegang kepemilikan terbesar) atau dengan kata lain good corporate governance diabaikan.

Beberapa literatur telah menunjukkan bahwa konsentrasi kepemilikan berpengaruh terhadap kualitas implementasi corporate governance suatu perusahaan. Jansen dan Meckling menyatakan bahwa manajer perusahaan yang memiliki tingkat kepemilikan tinggi atas suatu perusahaan, maka memungkinkan untuk melakukan diskresi terhadap sumber daya perusahaan akan berkurang (Jansen dan Meckling, 1976: 56). Adanya pengurangan diskresi atas sumber daya perusahaan tersebut pada akhirnya akan mempengaruhi aktivitas pemegang kendali sumber daya perusahaan, sehingga kualitas implementasi corporate governance akan mengarah kepada penghematan sumber daya dari aktivitas yang berlebihan dapat dilakukan. Implikasi dari pernyataan tersebut adalah konsentrasi kepemilikan mempengaruhi aktivitas diskresi sumber daya perusahaan yang selanjutnya mempengaruhi baik buruknya kualitas implementasi corporate governance.

Durnev dan Kim menyatakan bahwa dengan besarnya kepemilikan yang dimiliki oleh pemegang saham pengendali akan menghasilkan kebijakan-kebijakan dan prinsip-prinsip bisnis yang profitable yang pada akhirnya mampu meningkatkan kualitas implementasi corporate governance. Selain itu, kelemahan sistem hukum atau proteksi terhadap investor dapat diatasi dengan adanya konsentrasi kepemilikan yang menjadi alat yang lebih penting untuk mengatasi masalah keagenan (Durnev dan Kim, 2003: 28). Dengan adanya hal tersebut, terkadang konsentrasi kepemilikan dapat menaikkan bahkan mampu menurunkan kualitas implementasi corporate governance suatu perusahaan. Sedangkan Barucci dan Falini menemukan bahwa kepemilikan saham oleh pemegang saham pengendali berhubungan negatif dengan kualitas corporate governance (Barucci dan Falini dalam Deni Darmawati, 2006: 8).

$H_{1}$ : Konsentrasi kepemilikan pada suatu perusahaan berpengaruh terhadap kualitas implementasi corporate governance perusahaan.

\section{Set Kesempatan Investasi}

Set kesempatan investasi atau Investment opportunity set dikenalkan pertama kali oleh Myers pada tahun 1997. Set kesempatan investasi menurut Myers adalah kombinasi antara aktiva yang dimiliki perusahaan (assets in place) dan pemilihan investasi pada masa yang akan datang dengan net present value (NPV) yang positif (Myers dalam Isnaeni, 2005: 44). Set kesempatan investasi dapat meliputi pengeluaran modal untuk pengenalan produk baru atau untuk memperluas jangkauan pasar produk yang ada, alternatif pengeluaran untuk menekan biaya restrukturisasi perusahaan serta pilihan kebijakan akuntansi yang 
menguntungkan. Lebih lanjut Myers menyatakan bahwa semua biaya variable adalah bagian dari set kesempatan investasi. Sementara, menurut Gaver dan Gaver, set kesempatan investasi adalah nilai perusahaan yang besarnya tergantung pada pengeluaran di masa depan yang ditetapkan oleh manajemen. Pada saat ini dikenal sebagai alternatif investasi yang expected return-nya lebih besar (Gaver dan Gaver dalam Isnaeni, 2005: 44).

Nilai perusahaan dipengaruhi oleh dua hal yaitu aktiva yang saat ini telah ditempatkan dan opsi untuk investasi di masa depan. Set kesempatan investasi lebih ditekankan pada opsi investasi di masa depan. Opsi investasi di masa depan dapat diperoleh jika perusahaan memiliki projek dengan net present value yang positif (Kallapur dan Trombley dalam Isnaeni 2005: 45). Perlu diketahui bahwa set kesempatan investasi bukan merupakan pertumbuhan riil yang dicapai perusahaan saat ini, melainkan kesempatan perusahaan untuk tumbuh di masa mendatang. Sehingga ukuran set kesempatan investasi secara esensi selain dikaitkan dengan diperolehnya projek yang menguntungkan, ternyata dapat dikaitkan dengan investasi perusahaan terutama pada research and development atau aktiva tetap pada suatu perusahaan. Dengan melakukan investasi pada research and development dan aktiva tetap, kemungkinan perusahaan akan menikmati pertumbuhan riil di masa mendatang.

Ragam pengukuran set kesempatan investasi diantaranya dapat menggunakan faktor tunggal atau dengan menggunakan kombinasi beberapa faktor. Apabila ukuran data-data pasar modal dijadikan sebagai masukan pengukuran set kesempatan investasi, maka pengukuran set kesempatan investasi dapat menggunakan ukuran harga saham dan market value of equity sebagai proksi dari set kesempatan investasi. Selain itu, set kesempatan investasi dapat diamati dari pertumbuhan nilai buku perusahaan di masa mendatang, sehingga nilai perusahaan di masa mendatang akan tercermin dari harga saham, karena harga saham menceriminkan present value dari arus kas di masa mendatang yang akan diterima investor.

\section{Pengaruh Set Kesempatan Investasi Terhadap Kualitas Implementasi Corporate Governance Perusahaan}

Perusahaan yang memiliki set kesempatan investasi yang tinggi akan senantiasa melakukan ekspansi bisnis dan dengan demikian akan selalu membutuhkan dana eksternal. Berkaitan dengan hal tersebut, maka perusahaan akan berusaha untuk meningkatkan kualitas implementasi corporate governance untuk memudahkan didapatkannya dana eksternal dari investasi maupun utang dan menurunkan biaya modal (Durnev dan Kim, 2003: 28). Kebutuhan akan corporate governance yang berkualitas pada perusahaan yang memiliki set kesempatan investasi yang tinggi dan lebih menguntungkan akan berdampak pada return saham dari para pemegang saham perusahaan, return atas investasi dari pemegang saham pengendali akan lebih besar dibandingkan dengan manfaat yang akan mereka peroleh jika akan melakukan diskresi terhadap sumber daya perusahaan, sehingga akan menerapkan praktik corporate governance yang lebih berkualitas.

Adanya manajer pada perusahaan yang memiliki set kesempatan investasi yang tinggi akan memiliki kesempatan untuk melakukan diskresi/ekspropiasi yang lebih besar dalam pemilihan projek investasi, dibandingkan dengan manajer perusahaan yang kesempatan investasinya rendah. Penurunan set kesempatan investasi memiliki dampak terhadap terjadinya diskresi/ekspropiasi sumber daya perusahaan oleh para pemegang saham pengendali perusahaan. Dengan demikian, dalam perusahaan yang memiliki set kesempatan investasi yang tinggi membutuhkan kualitas implementasi corporate governance yang lebih baik (Gillan et. al., 2003: 22).

$\mathrm{H}_{2}$ : Set Kesempatan Investasi yang dimiliki oleh suatu perusahaan berpengaruh terhadap kualitas implementasi corporate governance perusahaan.

\section{Leverage Keuangan Perusahaan}


Leverage adalah pembiayaan modal suatu perusahaan dengan menggunakan proporsi utang yang lebih besar daripada modal sendiri yang dimiliki oleh perusahaan (Brigham dan Huston, 2001: 86). Total utang dalam suatu perusahaan pada umumnya meliputi utang lancar dan utang jangka panjang. keuangan, pengembalian atas aset -Return on Assets (ROA) lebih tinggi daripada tingkat bunga pinjaman, maka Return on Equity (ROE) akan lebih tinggi daripada jika tidak meminjam karena aset sama dengan ekuitas ditambah utang. Di sisi lain, jika ROA perusahaan lebih rendah daripada tingkat bunga, maka ROE akan lebih rendah daripada jika tidak Dalam leverage (juga dikenal sebagai gearing atau levering) mengacu pada penggunaan utang untuk berinvestasi. Financial leverage mengambil bentuk pinjaman,yang hasil penjualannya adalah (kembali) berinvestasi dengan maksud untuk memperoleh tingkat pengembalian yang lebih besar daripada biaya bunga.

\section{Pengaruh Leverage terhadap Kualitas Implementasi Corporate Governance Perusahaan}

Menurut Black et. al., pengaruh leverage keuangan pada suatu perusahaan terhadap kualitas implementasi corporate governance dapat ditinjau dari dua pandangan yaitu $a$ substitution story dan an investor pressure story (Black et. al., 2006: 14). Pandangan pertama (a substitution story) adalah perusahaan yang memiliki tingkat utang yang tinggi dalam struktur modalnya akan cenderung menjadi subjek untuk dikenai pengawasan oleh kreditor yang lebih ketat dan umumnya dinyatakan dalam kontrak utang yang dibuat oleh kedua belah pihak yang bersangkutan. Dengan demikian, perusahaan kurang begitu mementingkan kualitas implementasi corporate governance, karena sudah ada pengawasan dari pihak eksternal.

Pandangan kedua (an investor pressure story) adalah bahwa kreditor sangat berkepentingan dengan praktik corporate governance dari debiturnya dan memiliki kekuasaan yang lebih besar dibandingkan para pemegang saham untuk memaksa perusahaan untuk meningkatkan kualitas implementasi corporate governance perusahaan (jika perusahaan mendanai bisnisnya dengan proporsi utang yang tinggi dalam struktur modalnya). Gillan et. al. berhasil menemukan adanya hubungan negatif antara leverage dan kualitas implementasi corporate governance (Gillan et. al., 2003: 23). Namun, disisi lain penelitian yang dilakukan oleh Barucci dan Falini tidak berhasil menemukan adanya hubungan antara leverage dan kualitas implementasi corporate governance (Barucci dan Falini dalam Deni Darmawati, 2006: 8).

$H_{3}$ : Leverage keuangan perusahaan berpengaruh terhadap kualitas implementasi corporate governance perusahaan.

\section{Pengaruh Konsentrasi Kepemilikan, Set Kesempatan Investasi, dan Leverage terhadap Kualitas Implementasi Corporate Governance Perusahaan}

Jika dipandang secara parsial antara kosentrasi kepemilikan, set kesempatan investasi, dan leverage yang dimiliki perusahaan memiliki hubungan dan/pengaruh terhadap kualitas implementasi corporate governance-nya, maka kemungkinan secara simultan, beberapa karakteristik perusahaan tersebut mungkin dapat berhubungan dan berpengaruh terhadap kualitas implementasi corporate governance bagi suatu perusahaan. Hal tersebut dikarenakan pada dasarnya konsentrasi kepemilikan, set kesempatan investasi, dan leverage adalah beberapa karakter yang dimiliki oleh perusahaan dalam satu gabungan set karakteristik perusahaan secara bersama-sama. Dalam penelitian yang dilakukan oleh Deni Darmawati ditemukan bahwa konsentrasi kepemilikan, set kesempatan investasi, leverage, ukuran perusahaan, dan faktor regulasi secara bersama-sama mempengaruhi kualitas implementasi corporate governance (Deni Darmawati, 2006: 15). 


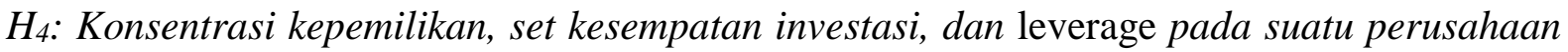
berpengaruh secara simultan terhadap kualitas implementasi corporate governance perusahaan.

\section{METODE PENELITIAN}

Jenis Penelitian ini adalah penelitian kausal komparatif, penelitian kausal komparatif adalah penelitian yang bertujuan untuk mengetahui kemungkinan adanya hubungan sebab akibat dengan cara tertentu berdasarkan atas pengamatan akibat yang ada, kemudian mencari kembali faktor yang diduga menjadi penyebabnya.

Populasi dalam penelitian ini adalah seluruh perusahaan yang terdaftar di Bursa Efek Indonesia tahun 2004 sampai dengan tahun 2008. Sedangkan sampel yang digunakan dalam penelitian ini adalah perusahaan yang terdaftar di Bursa Efek Indonesia (BEI) tahun 2004, 2005, 2006, 2007, dan 2008 yang masuk dalam pemeringkatan Corporate Governance Perception Index (CGPI) yang telah dilakukan oleh The Indonesian Institute for Corporate Governance (IICG).

Metode pengambilan sampel dalam penelitian ini menggunakan metode pemilihan sampel nonprobabilitas dengan pemilihan sampel berdasarkan tujuan (purposive sampling), yaitu pemilihan sampel secara tidak acak yang dilakukan dengan menggunakan pertimbangan (sesuai dengan tujuan atau masalah penelitian) tertentu (Nur Indriantoro dan Bambang Supomo, 2002: 131).

Tujuan penelitian ini adalah untuk menganalisis faktor-faktor yang berpengaruh terhadap kualitas implementasi corporate governance pada perusahaan yang masuk dalam sepuluh besar di Corporate Governance Perception Index (CGPI), karena dalam peringkat sepuluh besar Corporate Governance Perception Index (CGPI) tersebut terdapat sepuluh perusahaan di Indonesia yang memiliki kualitas implementasi corporate governance teratas yang mampu menarik perhatian investor dan kreditor. Perusahaan-perusahaan yang masuk dalam pemeringkatan sepuluh besar Corporate Governance Perception Index (CGPI), oleh pemakai informasi keuangan (termasuk investor dan kreditor) dipandang sebagai perusahaanperusahaan yang sangat baik dalam setiap peningkatan kinerjanya dan memiliki tingkat kesehatan bisnis yang sangat baik pula (Swa Sembada, 2009: 89-104), sehingga hal tersebut menjadi salah satu informasi yang dapat dijadikan sebagai dasar pengambilan keputusan berinvestasi bagi investor dan dapat dijadikan sebagai dasar pemberian pinjaman kredit bagi kreditor kepada perusahaan debitur. Berdasarkan tujuan dan alasan-alasan tesebut, maka peneliti menetapkan kriteria-kriteria pemilihan sampel yang akan diteliti sebagai berikut:

1. Perusahaan-perusahaan yang terdaftar di Bursa Efek Indonesia yang memiliki data keuangan di Indonesian Capital Market Directory (ICMD) atau telah menerbitkan laporan keuangan di Bursa Efek Indonesia (di situs www.idx.co.id) maupun di situs pribadi perusahaan sampel penelitian untuk tahun 2004, 2005, 2006, 2007, dan 2008.

2. Perusahaan-perusahaan yang terdaftar di Bursa Efek Indonesia (BEI) yang masuk dalam pemeringkatan Corporate Governance Perception Index (CGPI) yang telah dipublikasikan oleh The Indonesian Institute for Corporate Governance (IICG) pada majalah SWAsembada pada tahun 2004, 2005, 2006, 2007, dan 2008.

3. Perusahaan-perusahaan dalam Corporate Governance Perception Index (CGPI) yang termasuk dalam peringkat pertama sampai dengan peringkat kesepuluh (sepuluh besar) pada tahun 2004, 2005, 2006, 2007, dan 2008.

Berikut ini tahap-tahap perolehan hasil sampel perusahaan yang dijadikan objek penelitian:

Tabel 2: Tahap Pemerolehan Sampel Penelitian 


\begin{tabular}{|c|l|r|}
\hline Tahap & Kriteria & Jumlah \\
\hline I & $\begin{array}{l}\text { Perusahaan yang terdaftar di Bursa Efek Indonesia (BEI) sampai dengan } \\
\text { akhir tahun 2008 }\end{array}$ & 389 \\
\hline II & $\begin{array}{l}\text { Perusahaan yang mempublikasikan laporan keuangan, namun tidak } \\
\text { dipublikasikan di ICMD atau tidak dipublikasikan di situs perusahaan pada } \\
\text { tahun 2004 sampai dengan akhir tahun 2008 }\end{array}$ \\
\hline & $\begin{array}{l}\text { Perusahaan yang tidak masuk dalam pemeringkatan CGPI periode tahun } \\
\text { 2004 sampai dengan tahun 2008 }\end{array}$ \\
\hline III & \begin{tabular}{c} 
(199) \\
\hline IV
\end{tabular} & $\begin{array}{l}\text { Perusahaan yang tidak masuk dalam sepuluh besar pemeringkatan CGPI } \\
\text { dari tahun 2004 sampai dengan 2008 }\end{array}$ \\
\hline IV & $\begin{array}{l}\text { Perusahaan yang masuk dalam sepuluh besar pemeringkatan CGPI dari } \\
\text { tahun 2004 sampai dengan tahun 2008 (jumlah sampel penelitian) }\end{array}$ \\
\hline
\end{tabular}

Sumber: data sekunder diolah

\section{Pengukuran Variabel Penelitian}

\section{Kualitas Implementasi Corporate Governance}

Kualitas implementasi corporate governance merupakan sebuah penilaian tentang tata kelola perusahaan yang selanjutnya memunculkan predikat (terdiri atas predikat "sangat terpercaya", "terpercaya", dan "cukup terpercaya") bagaimana Good Corporate Governance (GCG) diimplementasikan oleh suatu perusahaan. Hasil pemeringkatan yang berupa skor nilai Corporate Governance Perception Index (CGPI) adalah alat ukur yang dipakai dalam mengukur seberapa baik kualitas implementasi corporate governance, dalam penelitian ini kualitas implementasi corporate governance dihitung dengan rumus yang dikembangkan oleh The Indonesian Institute of Corporate Governance (SWASembada, 2009: 91):

$\mathrm{KICG}=(15 \% \mathrm{X}$ Self Assessment $)+(25 \%$ X Kelengkapan Dokumen $)+(12 \% \mathrm{X}$

Makalah $)+(48 \%$ X Observasi)

\section{Konsentrasi Kepemilikan}

Struktur kepemilikan mengacu pada berbagai pola di mana pemegang saham dapat mengatur semua hal yang berkaitan dengan aktivitas perusahaan atas kelompok tertentu dalam kebijakan dan aktivitas bisnis perusahaan. Konsentrasi kepemilikan menggambarkan tentang bagaimana dan siapa saja yang memegang kendali atas keseluruhan atau sebagian besar atas kepemilikan perusahaan serta keseluruhan atau sebagian besar pemegang kendali atas aktivitas bisnis perusahaan tersebut. Ukuran konsentrasi kepemilikan suatu perusahaan diukur dengan menggunakan persentasi kepemilikan terbesar pada perusahaan (sesuai dengan rumus yang dikembangkan dalam ICMD) yang menjadi sampel penelitian dengan rumus sebagai berikut:

$$
\begin{aligned}
& \text { Konsentrasi Kepemilikan } \\
& =\frac{\text { Jumlah Kepemilikan saham terbesar }(\mathrm{d} l m \text { lbr atau } R p)}{\text { Total Saham perusahaan }(\mathrm{d} l \mathrm{~lm} l \mathrm{lbr} \text { atau } R p)} \times 100 \%
\end{aligned}
$$

\section{Set Kesempatan Investasi}

Set kesempatan investasi atau Investment opportunity Set (IOS) adalah kombinasi antara aktiva yang dimiliki perusahaan (assets in place) dan pemilihan investasi pada masa yang akan datang dengan net present value (NPV) yang positif (Myers dalam Isnaeni, 2005: 44). Set kesempatan investasi atau Investment opportunity Set (IOS) dapat meliputi 
pengeluaran modal untuk pengenalan produk baru atau untuk memperluas jangkauan pasar produk yang ada, alternatif pengeluaran untuk menekan biaya restrukturisasi perusahaan, pilihan kebijakan akuntansi yang menguntungkan. Lebih lanjut Myers menyatakan bahwa semua biaya variable adalah bagian dari set kesempatan investasi. Market Value to Book Value of Asset Ratio (MVABVA) adalah rasio yang digunakan untuk menilai set kesempatan investasi pada suatu perusahaan dengan cara menilai total aktiva perusahaan dikurangi dengan nilai total ekuitas ditambah dengan total nilai saham perusahaan pada tahun ke-t [(jumlah saham beredar x harga penutupan saham)/total aktiva]. Nilai Aktiva, ekuitas, dan nilai saham yang digunakan dalam menilai set kesempatan investasi ini adalah nilai pada akhir tahun yang diinformasikan pada laporan perubahan saham perusahaan. Alasan mendasar digunakannya rumus tersebut yaitu dengan dasar pemikiran bahwa prospek pertumbuhan perusahaan terefleksi dalam harga saham dan pasar menilai perusahaan yang sedang tumbuh (nilai harga saham) lebih besar dari nilai bukunya. Secara matematis rumus rasio nilai buku terhadap nilai pasar aktiva sebagai berikut (Isnaeni, 2005: 47-49):

$$
\begin{aligned}
& \text { MVABVA } \\
& =\frac{\text { Total Aktiva - Total Ekuitas }+}{\text { (Jml Saham Beredar Akhir Tahun X Nilai Penutupan Saham Akhir Tahun })}
\end{aligned}
$$

\section{Leverage}

Leverage adalah pembiayaan modal suatu perusahaan dengan menggunakan proporsi utang yang lebih besar daripada modal sendiri yang dimiliki oleh perusahaan (proporsi utang lebih besar dari pada proporsi ekuitas). Leverage keuangan perusahaan yang menjadi sampel penelitian diukur dengan menggunakan rasio total utang terhadap total aktiva yang dimiliki oleh perusahaan terkait. Leverage keuangan perusahaan dalam penelitian ini diukur dengan rumus sebagai berikut (Brigham dan Huston, 2001:

$$
\text { Leverage }=\frac{\text { Total Utang }}{\text { Total Aktiva }}
$$

\section{Pengumpulan dan Analisis Data}

Metode pengumpulan data yang digunakan dalam penelitian ini adalah metode dokumentasi. Data sekunder tersebut diambil dari The Indonesian Institute of Corporate Governance (IICG) tahun 2004 sampai dengan tahun 2008 yang berupa Corporate Governance Perception Index (CGPI) yang dipublikasikan pada majalah SWAsembada. Sedangkan pendokumentasian data lainnya (berupa nilai total asset, utang, ekuitas, data saham, dan persentase konsentrasi kepemilikan perusahaan) yang diperoleh melalui situs www.idx.co.id berupa data laporan keuangan perusahaan di Indonesian Stock Exchange (IDX), situs perusahaan sample penelitian, dan di Indonesian Capital Market Directory (ICMD) tahun 2004 sampai dengan tahun 2008.

Setelah memenuhi uji prasyarat analisis, maka pengujian hipotesis dilakukan dengan menganalisis faktor-faktor yang mempengaruhi kualitas implementasi corporate governance, dengan model berikut:

$\mathrm{KICG}=\mathrm{a}+\mathrm{b}_{1} \mathrm{KK}+\mathrm{b}_{2} \mathrm{SKI}+\mathrm{b}_{3} \mathrm{LEV}+\mathrm{e}$

Keterangan:

KICG : Kualitas Implementasi Corporate Governance

a : Konstanta

$\mathrm{b}_{1-3} \quad$ : Koefisien regresi

KK : Konsentrasi Kepemilikan

SKI : Set Kesempatan Investasi (Investment Opportunity Set)

LEV : Leverage Keuangan 
Pengujian tiga hipotesis individual ( $\mathrm{H} 1$ - H3) diuji dengan menggunakan uji signifikansi-t (Uji-t). Pengujian ini bertujuan untuk mengetahui pengaruh dari masing-masing variabel independen terhadap variabel dependennya. Uji signifikansi parameter individual $(\mathrm{t})$ dilakukan dengan membandingkan nilai probabilitas signifikansi yang dimiliki oleh masingmasing variabel independen dengan taraf signifikansi sebesar 5\%. Jika nilai probabilitas signifikansi yang dimiliki oleh masing-masing variabel independen lebih besar dari taraf signifikansi 5\% (sig > 0,05), maka bermakna bahwa variabel independen secara individual tidak berpengaruh signifikan terhadap variabel dependen, dan sebaliknya.

Hipotesis keempat (H4) diuji dengan menggunakan uji signifikansi-F (Uji-F). Pengujian ini bertujuan untuk mengetahui pengaruh variabel independen secara simultan terhadap variabel dependen dengan melihat nilai probabilitas signifikansi F. Nilai probabilitas signifikansi $\mathrm{F}$ dapat digunakan dalam pengujian untuk mengetahui apakan variasi nilai variabel independen dapat menjelaskan (explained) variasi nilai variabel dependen. Uji hipotesis keempat dilakukan dengan cara membandingkan antara nilai probabilitas signifikansi $\mathrm{F}$ dengan taraf signifikansi 5\%. Jika nilai probabilitas signifikansi $\mathrm{F}$ lebih besar dari taraf signifikansi 5\% (sig > 0,05), bermakna bahwa variabel independen secara simultan tidak berpengaruh signifikan terhadap variabel dependen dan sebaliknya.

\section{HASIL PENELITIAN}

\section{Deskripsi Data}

Populasi dalam penelitian ini adalah perusahaan yang terdaftar di Bursa Efek Indenesia (BEI) tahun 2004-2008. Data di Indonesian Stock Exchange (IDX) menunjukkan terdapat 389 perusahaan yang listing sampai dengan akhir tahun 2008. Data penelitian terkait perusahaan yang menjadi sampel penelitian (perusahaan yang masuk dalam CGPI) diperoleh dari publikasi Corporate Governance Perception Index (CGPI) oleh The Indonesian Institute for Corporate Governance (IICG) pada majalah SWA Sembada. Sedangkan untuk data penelitian terkait data keuangan perusahaan yang menjadi sampel penelitian diperoleh di Indonesian Capital Market Directory (ICMD), Indonesian Stock Exchange (IDX). Berdasarkan teknik pengambilan sampel yang digunakan dalam penelitian ini (purposive sampling), diperoleh sampel sebanyak 50 perusahaan. Namun setelah dilakukan pengkajian dan pencermatan terhadap kelima puluh sampel tersebut terdapat satu outlier, yaitu perusahaan PT Bank Bumiputera Indonesia Tbk (pada tahun 2004). Dengan adanya penghilangan satu data dalam penelitian yang dinyatakan outlier, maka sampel penelitian berkurang satu maka yang menjadi sampel dalam penelitian ini menjadi 49 perusahaan, yaitu:

Tabel 3: Daftar Perusahaan Sampel Penelitian

\begin{tabular}{|l|l|l|l|l|}
\hline No & Tahun & \multicolumn{1}{|c|}{ Nama Perusahaan } & Nilai CGPI & Predikat KICG \\
\hline 1 & 2004 & PT Astra International Tbk. & 81.2 & Terpercaya \\
\hline 2 & 2005 & PT Astra International Tbk. & 85.87 & Sangat Terpercaya \\
\hline 3 & 2006 & PT Bank Niaga Tbk & 89.27 & Sangat Terpercaya \\
\hline 4 & 2007 & PT Bank Mandiri Tbk. & 88.66 & Sangat Terpercaya \\
\hline 5 & 2008 & PT Bank Mandiri (Persero) Tbk. & 89.86 & Sangat Terpercaya \\
\hline 6 & 2004 & PT Unilever Indonesia Tbk. & 76.86 & Terpercaya \\
\hline 7 & 2005 & PT Bank Central Asia Tbk. & 85.14 & Sangat Terpercaya \\
\hline 8 & 2006 & PT Medco Energi International Tbk & 87.4 & Sangat Terpercaya \\
\hline 9 & 2007 & PT Bank Niaga Tbk. & 87.9 & Sangat Terpercaya \\
\hline 10 & 2008 & PT Bank CIMB Niaga Tbk. & 88.3 & Sangat Terpercaya \\
\hline
\end{tabular}




\begin{tabular}{|c|c|c|c|c|}
\hline No & Tahun & Nama Perusahaan & Nilai CGPI & Predikat KICG \\
\hline 11 & 2004 & PT Astra Graphia Tbk. & 76.76 & Terpercaya \\
\hline 12 & 2005 & PT Bank Niaga Tbk. & 84.23 & Terpercaya \\
\hline 13 & 2006 & PT Bank Mandiri Tbk & 83.66 & Terpercaya \\
\hline 14 & 2007 & PT Aneka Tambang Tbk. & 82.07 & Terpercaya \\
\hline 15 & 2008 & PT United Tractors Tbk. & 83.42 & Terpercaya \\
\hline 16 & 2004 & PT Medco Energi International Tbk & 74.86 & Terpercaya \\
\hline 17 & 2005 & PT Dankos Laboratories Tbk. & 83.72 & Terpercaya \\
\hline 18 & 2006 & PT Astra International Tbk & 83.01 & Terpercaya \\
\hline 19 & 2007 & PT Adhi Karya Tbk. & 81.79 & Terpercaya \\
\hline 20 & 2008 & PT Aneka Tambang Tbk. & 83.41 & Terpercaya \\
\hline 21 & 2004 & PT Bank Niaga Tbk. & 74.16 & Terpercaya \\
\hline 22 & 2005 & PT Bank Permata Tbk. & 83.33 & Terpercaya \\
\hline 23 & 2006 & PT Aneka Tambang Tbk & 81.92 & Terpercaya \\
\hline 24 & 2007 & PT United Tractors Tbk & 81.53 & Terpercaya \\
\hline 25 & 2008 & PT Adi Karya (Persero) Tbk & 82.07 & Terpercaya \\
\hline 26 & 2004 & PT Kalbe Farma Tbk. & 72.84 & Terpercaya \\
\hline 27 & 2005 & PT BFI Finance Indonesia Tbk & 82.55 & Terpercaya \\
\hline 28 & 2006 & PT Telkom (Persero) Tbk & 81.3 & Terpercaya \\
\hline 29 & 2007 & PT Tambang Batubara Bukit Asam Tbk. & 80.87 & Terpercaya \\
\hline 30 & 2008 & PT Tambang Batubara Bukit Asam Tbk. & 81.23 & Terpercaya \\
\hline 31 & 2004 & PT Dankos Laboratories Tbk. & 72.46 & Terpercaya \\
\hline 32 & 2005 & PT Astra Argo Lestari Tbk. & 82.31 & Terpercaya \\
\hline 33 & 2006 & PT BNI 1946 (Persero) Tbk & 79.39 & Terpercaya \\
\hline 34 & 2007 & PT Astra Graphia Tbk. & 80.3 & Terpercaya \\
\hline 35 & 2008 & PT Krakatau Steel (Persero) & 80.7 & Terpercaya \\
\hline 36 & 2005 & PT Bank Bumiputera Indonesia Tbk. & 81.29 & Terpercaya \\
\hline 37 & 2006 & PT Kalbe Farma Tbk & 78.7 & Terpercaya \\
\hline 38 & 2007 & PT Kalbe Farma Tbk. & 79.7 & Terpercaya \\
\hline 39 & 2008 & PT Indosat Tbk. & 80.24 & Terpercaya \\
\hline 40 & 2004 & PT BFI Finance Indonesia Tbk. & 68.6 & Cukup Terpercaya \\
\hline 41 & 2005 & PT Astra Graphia Tbk. & 80.52 & Terpercaya \\
\hline 42 & 2006 & PT Astra Graphia Tbk & 78.33 & Terpercaya \\
\hline 43 & 2007 & PT Bank BNI (Persero) Tbk. & 79.46 & Terpercaya \\
\hline 44 & 2008 & PT Bank NISP Tbk. & 79.83 & Terpercaya \\
\hline 45 & 2004 & PT Bimantara Citra & 68.56 & Cukup Terpercaya \\
\hline 46 & 2005 & PT Kalbe Farma Tbk. & 80.24 & Terpercaya \\
\hline 47 & 2006 & PT Apexindo Pratama Duta Tbk & 77.58 & Terpercaya \\
\hline 48 & 2007 & PT Bank Permata Tbk. & 78.85 & Terpercaya \\
\hline 49 & 2008 & PT Wijaya Karya Tbk. & 78.55 & Terpercaya \\
\hline
\end{tabular}

Sumber: SWA 09/XXI/28 April-11 Mei 2005, SWA 26/XXII/11-20 Desember 2006, SWA 01/XXIV/9-23 Januari 2008, SWA 27/XXIV/18 Desember 2008-7 Januari 2009 diolah.

Hasil statistik deskriptif masing-masing variable tampak sebagi berikut: 
Tabel 4: Statistik Deskriptif

\begin{tabular}{|l|l|r|r|r|r|}
\hline Variabel & $\mathrm{N}$ & Minimum & Maximum & Mean & Std. Deviation \\
\hline KK & 49 & 0,10 & 0,97 & 0,5863 & 0,19772 \\
\hline SKI & 49 & 0,61 & 78,01 & 3,2654 & 10,98423 \\
\hline LEV & 49 & 0,04 & 0,95 & 0,6025 & 0,26302 \\
\hline KICG & 49 & 68,56 & 89,86 & 80,9143 & 4,68768 \\
\hline
\end{tabular}

Sumber: data sekunder diolah

Pengujian terhadap hipotesis dalam penelitian ini menggunakan analisis regresi linear berganda. Analisis regresi dipakai untuk mencari bersarnya hubungan dan juga menentukan besarnya pengaruh variabel independen terhadap variabel dependennya, yaitu konsentrasi kepemilikan (KK), set kesempatan investasi (SKI), dan leverage (LEV) terhadap kualitas implementasi corporate governance (KICG). Pengujian hipotesis dalam penelitian ini menggunakan analisis regresi linear berganda sebagai berikut:

$\mathrm{KICG}=\mathrm{a}+\mathrm{b}_{1} \mathrm{KK}+\mathrm{b}_{2} \mathrm{SKI}+\mathrm{b}_{3} \mathrm{LEV}+\mathrm{e}$

Keterangan:

KICG : Kualitas Implementasi Corporate Governance

a : Konstanta

$\mathrm{b}_{1-3} \quad$ : Koefisien regresi

KK : Konsentrasi Kepemilikan

SKI : Set Kesempatan Investasi (Investment Opportunity Set)

LEV : Leverage Keuangan

e : Error

Berikut ini hasil uji signifikansi masing-masing variabel

Tabel 5: Hasil Uji Signifikansi Masing-masing Variabel

\begin{tabular}{|l|r|r|r|r|r|}
\hline \multirow{2}{*}{ Model } & \multicolumn{2}{|c|}{$\begin{array}{c}\text { Unstandardized } \\
\text { Coefficients }\end{array}$} & $\begin{array}{c}\text { Standardized } \\
\text { Coefficients }\end{array}$ & \multirow{2}{*}{$\mathrm{t}$} & \multirow{2}{*}{ Sig. } \\
\cline { 2 - 4 } & \multicolumn{1}{c|}{ B } & Std. Error & \multicolumn{1}{c|}{ Beta } & & \\
\hline Constant & 75,475 & 2,319 & & 32,547 & 0,000 \\
\hline KK & 2,627 & 3,229 & 0,111 & 0,814 & 0,420 \\
\hline SKI & 0,070 & 0,058 & 0,163 & 1,199 & 0,237 \\
\hline LEV & 6,094 & 2,443 & 0,342 & 2,494 & 0,016 \\
\hline
\end{tabular}

Sumber: data sekunder diolah

Berdasarkan hasil uji signifikansi masing-masing variable pada tabel 5 di atas dihasilkan bahwa variabel konsentrasi kepemilikan (KK) memiliki nilai t sebesar 0,814 dengan probabilitas signifikansi 0,420 dan variabel set kesempatan invenstasi (SKI) memiliki nilai t sebesar 1,199 dengan probabilitas signifikansi 0,237. Nilai probabilitas signifikansi t yang lebih besar dari taraf signifikansi 5\%, dapat disimpulkan bahwa variabel independen tidak mempengaruhi variabel dependen secara signifikan. Sedangkan variabel leverage memiliki nilai $\mathrm{t}$ sebesar 2,494 dengan probabilitas signifikansi 0,016 . Nilai probabilitas signifikansi $\mathrm{t}$ yang lebih kecil dari taraf signifikansi 5\% disimpulkan bahwa variabel independen berpengaruh secara signifikan terhadap variabel dependen. Apabila diterapkan dalam persamaan regresi akan tampak sebagai berikut:

$\mathrm{KICG}=75,475+2,627 \mathrm{KK}+0,070 \mathrm{SKI}+6,094 \mathrm{LEV}+\mathrm{e}$

Uji signifikansi simultan dilakukan untuk menguji pengaruh variabel independen secara simultan terhadap variabel dependen. Berikut ini hasil uji signifikansi simultan (UjiF): 
Tabel 6: Hasil Uji Signifikansi Simultan (Uji-F)

\begin{tabular}{|l|r|r|r|r|r|}
\hline \multicolumn{1}{|c|}{ Model } & $\begin{array}{c}\text { Sum of } \\
\text { Squares }\end{array}$ & Df & $\begin{array}{c}\text { Mean } \\
\text { Square }\end{array}$ & F & Sig. \\
\hline $\begin{array}{l}\text { Regressio } \\
\mathrm{n}\end{array}$ & 190,272 & 3 & 63,424 & 3,301 & $\begin{array}{r}0,029 \\
\mathrm{a}\end{array}$ \\
\hline Residual & 864,499 & 45 & 19,211 & \\
\hline Total & 1054,770 & 48 & & \\
\hline
\end{tabular}

Sumber: data sekunder diolah

Berdasarkan hasil uji signifikansi simultan (Uji-F) pada tabel 6, dihasilkan nilai $\mathrm{F}$ hitung sebesar 3,301 dengan probabilitas signifikansi sebesar 0,029. Karena nilai probabilitas signifikansi $\mathrm{F}$ tersebut lebih kecil dari taraf signifikansi 5\%, maka dapat disimpulkan bahwa model regresi dapat digunakan untuk memprediksi kualitas implementasi corporate governance (KICG) atau dapat dikatakan bahwa variabel konsentrasi kepemilikan, set kesempatan investasi, dan leverage berpengaruh signifikan terhadap kualitas implementasi corporate governance (KICG).

\section{Hasil Uji Hipotesis Pertama}

Berdasarkan tabel 5, dihasilkan nilai t sebesar 0,814 dengan probabilitas signifikansi sebesar 0,420 pada variabel konsentrasi kepemilikan (KK). Jika dibandingkan dengan taraf signifikansi 5\%, maka nilai probabilitas signifikansi pada variabel konsentrasi kepemilikan lebih besar dari nilai taraf signifikansi $(0,420>0,05)$. Karena nilai probabilitas signifikansi variabel konsentrasi kepemilikan lebih besar dari taraf nilai signifikansi 5\%, maka dapat disimpulkan bahwa secara individual konsentrasi kepemilikan tidak berpengaruh terhadap kualitas implementasi corporate governance. Jadi, hipotesis pertama tidak didukung.

\section{Hasil Uji Hipotesis Kedua}

Pada variabel set kesempatan investasi (SKI) dihasilkan nilai t sebesar 1,199 dengan probabilitas signifikansi sebesar 0,237 (tabel 5). Jika dibandingkan dengan taraf signifikansi 5\%, maka nilai probabilitas signifikansi pada variabel set kesempatan investasi lebih besar dari nilai taraf signifikansi $(0,237>0,05)$. Karena nilai probabilitas signifikansi variabel set kesempatan investasi lebih besar dari taraf nilai signifikansi 5\%, maka dapat disimpulkan bahwa secara individual set kesempatan investasi tidak berpengaruh terhadap kualitas implementasi corporate governance. Jadi, hipotesis kedua tidak didukung.

\section{Hasil Uji Hipotesis Ketiga}

Berdasarkan tabel 5, dihasilkan nilai t sebesar 2,494 dengan probabilitas signifikansi sebesar 0,016 pada variabel leverage (LEV). Jika dibandingkan dengan taraf signifikansi 5\%, maka nilai probabilitas signifikansi pada variabel leverage lebih kecil dari nilai taraf signifikansi $(0,016<0,05)$. Karena nilai probabilitas signifikansi variabel leverage lebih kecil dari taraf signifikansi 5\%, maka dapat disimpulkan bahwa secara individual leverage berpengaruh terhadap kualitas implementasi corporate governance. Jadi, hipotesis ketiga didukung.

\section{Hasil Uji Hipotesis Keempat}


Berdasarkan hasil uji signifikansi simultan (F) pada tabel 6, dihasilkan nilai $\mathrm{F}$ hitung sebesar 3,301 dengan probabilitas signifikansi sebesar 0,029. Karena nilai probabilitas signifikansi $(0,029)$ ini lebih kecil dari taraf signifikansi 5\%, maka dapat disimpulkan bahwa konsentrasi kepemilikan, set kesempatan investasi, dan leverage secara signifikan mempengaruhi kualitas implementasi corporate governance (KICG). Jadi, hipotesis keempat (konsentrasi kepemilikan, set kesempatan investasi, dan leverage pada suatu perusahaan berpengaruh secara simultan terhadap kualitas implementasi corporate governance perusahaan) didukung.

\section{PEMBAHASAN}

Berdasarkan tabel 5, dihasilkan probabilitas signifikansi pada variabel konsentrasi kepemilikan (KK) sebesar 0,420. Karena nilai probabilitas signifikansi tersebut lebih besar dari taraf signifikansi 5\%, maka dapat disimpulkan bahwa secara individual konsentrasi kepemilikan tidak berpengaruh terhadap kualitas implementasi corporate governance. Kesimpulannya, hipotesis pertama (konsentrasi kepemilikan pada suatu perusahaan berpengaruh secara individual terhadap kualitas implementasi corporate governance perusahaan) ditolak (tidak didukung). Hasil penelitian ini sesuai dengan pandangan kedua yang dikemukakan oleh Drobetz et.al. (2004) pada penelitiannya terhadap nilai rating corporate governance pada perusahaan yang berada di Jerman pada tahun 2004.

Hasil pengujian menunjukkan bahwa semakin terkonsentrasinya kepemilikan perusahaan, maka pemegang saham mayoritas akan semakin menguasai perusahaan dan semakin mempengaruhi pengambilan keputusan (termasuk keputusan untuk tidak mengimplementasikan corporate governance). Selain itu, pemegang saham mayoritas akan berpandangan bahwa bukan menjadi kepentingan mereka lagi mengenai perlindungan kepada para pemegang saham minoritas dan mekanisme corporate governance. Hal ini mengindikasikan bahwa kualitas implementasi corporate governance yang baik diabaikan. Karena kualitas implementasi corporate governance diabaikan, maka dapat disimpulkan bahwa konsentrasi kepemilikan pada suatu perusahaan tidak mempengaruhi kualitas implementasi corporate governance perusahaan.

Hipotesis kedua dalam penelitian ini adalah set kesempatan investasi yang dimiliki oleh suatu perusahaan berpengaruh secara individual terhadap kualitas implementasi corporate governance. Pada variabel set kesempatan investasi (SKI) dihasilkan nilai probabilitas signifikansi sebesar 0,237 (tabel 5). Karena nilai probabilitas signifikansi tersebut lebih besar dari taraf nilai signifikansi 5\%, maka dapat disimpulkan bahwa secara individual set kesempatan investasi tidak berpengaruh terhadap kualitas implementasi corporate governance. Jadi, hipotesis kedua ditolak (tidak didukung).

Hasil penelitian ini sesuai dengan hasil penelitian yang dilakukan oleh Deni Darmawati (2006), yaitu set kesempatan investasi tidak berpengaruh terhadap kualitas implementasi corporate governance pada perusahaan yang masuk dalam pemeringkatan CGPI di Indonesia pada tahun 2003 sampai dengan tahun 2004. Menurut Kallapur dan Trombley (2001), set kesempatan investasi pada suatu perusahaan merupakan suatu komponen penting dari nilai pasar. Kallapur dan Trombley juga menyimpulkan bahwa adanya set kesempatan investasi pada suatu perusahaan mempengaruhi cara pandang manajer, pemilik perusahaan, investor, dan kreditor terhadap perusahaan (terutama aktivitas bisnisnya).

Menurut Wah (2002), perusahaan dengan set kesempatan investasi yang tinggi lebih mungkin untuk memiliki salah satu proksi kualitas laba berupa akrual kelolaan (discretionary accrual) yang tinggi, namun jika mereka memakai jasa auditor big 5 akrual kelolaan perusahaan menjadi menurun. Berdasarkan hal tersebut Wah (2002) kemudian menyimpulkan bahwa manajer dari suatu perusahaan yang memiliki set kesempatan investasi 
yang tinggi cenderung untuk memanipulasi akrual kelolaan, namun kecenderungan tersebut akan menurun jika perusahaan memiliki pengawasan audit yang lebih baik.

Berdasarkan hasil penelitian terdahulu dan hasil penelitian ini, maka dapat disimpulkan bahwa kemungkinan adanya set kesempatan investasi dapat digunakan oleh manajer untuk memanipulasi akrual kelolaan pada suatu perusahaan. Kegiatan manipulasi tersebut menunjukkan bahwa kualitas implementasi corporate governance perusahaan diabaikan, karena prinsip keadilan, transparasi, dan responsibilitas yang termasuk dalam prinsip-prinsip corporate governance telah diabaikan. Karena kualitas implementasi corporate governance diabaikan, maka dapat disimpulkan bahwa set kesempatan investasi pada suatu perusahaan tidak mempengaruhi kualitas implementasi corporate governance perusahaan.

Hipotesis ketiga dalam penelitian ini adalah leverage keuangan perusahaan berpengaruh secara individual terhadap kualitas implementasi corporate governance perusahaan. Berdasarkan tabel 5, dihasilkan nilai probabilitas signifikansi sebesar 0,016 pada variabel leverage (LEV). Nilai tersebut merupakan nilai lebih kecil dari nilai taraf signifikansi $(0,016<0,05)$. Karena nilai probabilitas signifikansi variabel leverage lebih kecil dari taraf signifikansi 5\%, maka dapat disimpulkan bahwa secara individual leverage berpengaruh terhadap kualitas implementasi corporate governance. Jadi, hipotesis ketiga (leverage perusahaan berpengaruh secara individual terhadap kualitas implementasi corporate governance perusahaan) didukung.

Hasil penelitian ini sesuai dengan hasil penelitian yang diungkapkan oleh Black et.al (2006) atas penelitiannya terhadap corporate governance pada perusahaan-perusahaan di Korea, bahwa leverage mempengaruhi kualitas implementasi corporate governance. Dalam pandangan kedua yang diungkapkan oleh Black et.al. (2006), dijelaskan bahwa kreditor sangat berkepentingan dengan praktik corporate governance dari debiturnya dan memiliki kekuasaan yang lebih besar dibandingkan dengan para pemegang saham untuk memaksa perusahaan menigkatkan kualitas corporate governance perusahaan. Sehingga dapat disimpulkan bahwa leverage dapat mempengaruhi kualitas implementasi corporate governance suatu perusahaan, karena dengan adanya utang akan memaksa perusahaan untuk meningkatkan manajemen utang yang baik yang selanjutnya juga akan menigkatkan kualitas implementasi corporate governance.

Hipotesis keempat dalam penelitian ini adalah konsentrasi kepemilikan, set kesempatan investasi, dan leverage pada suatu perusahaan berpengaruh secara simultan terhadap kualitas implementasi corporate governance. Berdasarkan hasil uji signifikansi simultan (F) pada tabel 6 dihasilkan nilai probabilitas signifikansi sebesar 0,029. Karena nilai probabilitas signifikansi ini $(0,029)$ lebih kecil dari taraf signifikansi 5\%, maka dapat disimpulkan bahwa konsentrasi kepemilikan, set kesempatan investasi, dan leverage secara simultan berpengaruh terhadap kualitas implementasi corporate governance (KICG). Jadi, hipotesis keempat (konsentrasi kepemilikan, set kesempatan investasi, dan leverage pada suatu perusahaan berpengaruh secara simultan terhadap kualitas implementasi corporate governance perusahaan) didukung. Hasil penelitian ini sesuai dengan hasil penelitian yang diungkapkan oleh Deni Darmawati (2006) yang menguji pengaruh karakteristik perusahaan dan faktor regulasi terhadap kualitas implementasi corporate governance, yaitu karakteristik perusahaan dan faktor regulasi berpengaruh secara simultan terhadap kualitas implementasi corporate governance.

Berdasarkan hasil penelitian terdahulu dan hasil penelitian ini, maka dapat disimpulkan bahwa sebuah tata kelola perusahaan yang baik (Good Corporate Governance) dalam implementasinya memerlukan kesatuan yang dimiliki oleh suatu perusahaan atas unsur-unsur finansial (seperti penentuan aktiva, utang, ekuitas, investasi dalam suatu perusahaan, penjualan, dan sebagainya) maupun unsur-unsur nonfinansial (seperti sususan 
organisasi perusahaan). Jika Corporate Governance tidak diimplementasikan dengan kedua hal tersebut secara simultan dari unsur yang bersifat finansial maupun nonfinansial maka tata kelola perusahaan yang diimplementasikan bukan merupakan sebuah tata kelola perusahaan, melainkan hanya implementasi sebuah subsistem pada suatu perusahaan. Jadi, dapat disimpulkan bahwa kesatuan unsur-unsur finansial maupun nonfinansial dalam suatu perusahaan merupakan suatu kesatuan yang mampu mempengaruhi kualitas implementasi corporate governance pada suatu perusahaan.

\section{KESIMPULAN}

Berdasarkan hasil penelitian dan pembahasan di atas maka dapat disimpulkan bahwa determinan kualitas implementasi corporate governance dalam studi ini adalah konsentrasi kepemilikan, set kesempatan investasi dan leverage. Namun dari hasil pengujian dan analisis ternyata hanya variabel leverage saja yang berpengaruh signifikan terhadap kualitas implementasi corporate governance. Demikian juga apabila ketiga variable tersebut diregresikan secara simultan, ternyata memiliki pengaruh signikan. Lebih lanjut, pengaruh masing-masing variabel adalah sebagai berikut:

Variabel konsentrasi kepemilikan yang terdapat pada suatu perusahaan secara individual tidak berpengaruh terhadap kualitas implementasi corporate governance. Hal ini terbukti dengan adanya hasil uji signifikansi parameter individual (t) (tabel 5) pada variabel konsentrasi kepemilikan (KK) dengan nilai t hitung sebesar 0,814 dan nilai probabilitas signifikansi sebesar 0,420 yang tidak signifikan karena termasuk nilai yang lebih besar dari nilai taraf signifikansi $5 \%(0,420>0,05)$.

Variabel set kesempatan investasi (investment opportunity set) yang ada pada suatu perusahaan secara individual ternyata juga tidak berpengaruh terhadap kualitas implementasi corporate governance. Kesimpulan ini diperoleh berdasarkan hasil uji signifikansi parameter individual nilai (t) (table 5) dengan nilai t sebesar 1,199 dan nilai probabilitas signifikansi sebesar 0,237. Nilai probabilitas signifikansi variabel set kesempatan investasi (SKI) ini tidak signifikan karena merupakan nilai yang lebih besar dari taraf signifikansi 5\% (0,237 > 0,05).

Variabel leverage yang dugunakan dalam struktur permodalan pada suatu perusahaan secara individual berpengaruh terhadap kualitas implementasi corporate governance. Hal ini dibuktikan dengan adanya hasil uji signifikansi parameter individual nilai (t) (tabel 5), pada variabel leverage diketahui nilai t sebesar 2,494 dengan nilai probabilitas signifikansi sebesar 0,016, nilai probabilitas sinifikansi ini merupakan nilai yang yang signifikan karena lebih kecil dari taraf signifikansi 5\% $(0,016<0,05)$.

Variabel konsentrasi kepemilikan, set kesempatan investasi, dan leverage secara simultan terbukti berpengaruh terhadap kualitas implementasi corporate governance. Kesimpulan ini diambil berdasarkan hasil uji signifikansi simultan (F) pada tabel 6 . Berdasarkan table tersebut dihasilkan nilai $\mathrm{F}$ hitung sebesar 3,301 dengan probabilitas signifikansi sebesar 0,029 yang mana nilai tersebut merupakan nilai yang signifikan karena lebih kecil dari taraf signifikansi $5 \%(0,029<0,05)$. 


\section{DAFTAR PUSTAKA}

Barucci, E. dan J. Falini. (2004). Determinant of Corporate Governance in the Italian Financial Market. Economic notes: Review of Banking, Finance, and Monetary Economic. Vol. 34. No. 3. Hal 371-405.

Black, B. S., H. Jang, dan W. Kim. (2006). Predicting Firm's Corporate Governance Choices: Evidence from Korea. The Journal of Finance. Vol. 12. No. 16: Hal. 23.

Brigham, Eugene F. dan Joel F. Houston. (2001). Manajemen Keuangan. Buku I. Edisi ke-8. Jakarta: Erlangga.

Davies. A. (1999). A Strategic Approach to Corporate Governance. England: Gower Publishing Limited.

Diah Kusuma Wardani. (2008). Pengaruh Corporate Governance terhadap Kinerja Perusahaan Di Indonesia. Skripsi. Fakultas Ekonomi Universitas Islam Indonesia

Deni Darmawati. (2006). Pengaruh Karakteristik Perusahaan dan Faktor Regulasi terhadap Kualitas Implementasi Corporate Governance. Simposium Nasional Akuntansi. Padang, 23-26 Agustus 2006.

Drobetz, W., K. Gugler, dan S. Hirschvogl. (2004). The Determinants of The German Corporate Governancerating. Working Paper.

Durnev, A. dan E. Han Kim. (2003). To Steal or Not To Steal: Firm Attributes. Legal Environment, and Valuation. The Journal of Finance. Vol. LX. No. 3: Hal.1464.

ECFIN. Indonesian Capital Market Directory. 2004, 2005, 2006, 2007, 2008, 2009.

Eisenhardt, Kathleem. M. (1989). Agency Theory: An Assesment and Review. Academy of Management Review. Vol.14. No.1: Hal 57-74.

Gillan, S. L., J. C. Hartzell, dan L. T. Starks. (2003). Industries, Investment Opportunities, and Corporate Governance Structure. Working Paper.

Isnaeni Rohayati. (2005). Analisis Hubungan Investment Opportunity Set (IOS) dengan Realisasi Pertumbuhan serta Perbedaan Perusahaan yang Tumbuh dan Tidak Tumbuh terhadap Kebijakan Pendanaan dan Dividen di Bursa Efek Jakarta. SMART. Vol. 1. No. 2: Hal. 41-60.

Jensen, Michael C. dan W.H. Meckling. (1976). Theory of The Firm: Managerial Behavior, Agency Cost and Ownership Structure. Journal of Financial Economics 3. Hal. 305360.

Jogiyanto Hartono. (2008). Teori Portofolio dan Analisis Investasi. Edisi Kelima. Yogyakarta: BPFE Yogya. 
Kallapur, Sanjay dan Mark A. Trombley. (2001). The Investment Opportunity Set: Determinants, Consequences and Measurement. Managerial Finance. Vol. 27 (3): 315.

Muh. Arief Ujiyanto dan Bambang Agus Pramuka. (2007). Mekanisme Corporate Governance, Manajemen Laba, dan Kinerja Keuangan. Simposium Nasional Akuntansi X. Vol. 10. Hal. 6.

Nur Indriantoro dan Bambang Supomo. (2002). Metode Penelitian Bisnis untuk Akuntansi dan Manajemen, Edisi Pertama. Yogyakarta: BPFE.

Organization for Economic Co-operation and Development. (2004). OECD Principles of Corporate Governance. Paris: OECD Publication Services.

Purbayu Budi Santoso dan Ashari. (2005). Analisis Statistik dengan Microsoft Excel dan SPSS. Yogyakarta: Penerbit Andi.

Rudi Isnanta. (2008). Pengaruh Corporate Governance dan Struktur Kepemilikan terhadap Manajemen Laba dan Kinerja Keuangan. Skripsi. Fakultas Ekonomi Universitas Islam Indonesia.

SWA Sembada, SWA 01/XXIV/9-23 Januari 2008.

SWA Sembada, SWA 09/XXI/28 April-11 Mei 2005.

SWA Sembada, SWA 26/XXII/11-20 Desember 2006.

SWA Sembada, SWA 27/XXIV/18 Desember 2008-7 Januari 2009.

The Indonesian Intitute for Corporate Governance. (2006). Laporan Corporate Governance Perception Index 2005. Jakarta: IICG. . (2009). Corporate Governance Perception Index 2008-Good Corporate Governance dalam Perspektif Manajemen Stratejik. Jakarta: IICG.

Wah, Lai Kam. (2002). Investment Opportunity and Audit Quality. http://papers.ssrn.com (diakses tanggal 7 April 2010).

Witmore, John. (1997). Coaching for Performance. London: Nicholas Brealey Publishing ltd. http://search.barnesandnoble.com/Coaching-for-Performance-4th-Edition/JohnWhitmore/e/9781857885354, diakses tanggal 28 Maret 2010)

www.idx.co.id (diakses tanggal 1 Februari sampai dengan 7 April 2010).

www.iicg.org (diakses tanggal 1 Februari sampai dengan 7 April 2010).

www.oecd.org (diakses tanggal 1 Februari sampai dengan 7 April 2010). 
Yunita Heryani Mintara. (2008). Pengaruh Implementasi Corporate Governance terhadap Pengungkapan Informasi. Skripsi. Fakultas Ekonomi Universitas Islam Indonesia.

Yuthi Aghnia. (2009). Good Corporate Governance. (http://yuthiaghnia.blogspot.com, diakses tanggal 29 Maret 2010) 